\title{
SSPN Gene
}

National Cancer Institute

\section{Source}

National Cancer Institute. SSPN Gene. NCI Thesaurus. Code C24825.

This gene plays a role in cellular membrane stabilization. 